\title{
WAVELET ANALYSIS OF THE BALTIC REGION RIVER RUNOFF LONG-TERM TRENDS AND FLUCTUATIONS
}

\author{
Andrejs Timuhins*, Valērijs Rodinovs, and Māris Kḷaviṇš \\ * Faculty of Physics and Mathematics, University of Latvia, Zelֶu 8, Rīga, LV-1002, LATVIA \\ Faculty of Geography and Earth Sciences, University of Latvia, Raina bulv. 19, LV-1586, Rīga, LATVIA \\ E-mail: maris.klavins@lu.Iv
}

Contributed by Māris Kḷaviṇš

The study of changes in river discharge and flood regime can provide important information on climate change and its impacts. Wavelet analysis offers new possibilities to study changes of river discharge patterns in regard to periodical processes on a background of climate change. In this study wavelet analysis was used to study long-term changes of river discharge in the Baltic region. Periodic oscillations of discharge intensity, and low- and high-water flow years are common for the major rivers in the Eastern Baltic region. Main frequencies of river discharge were estimated to be 14, 28, 37 years for the studied rivers. Wavelet analysis allowed to identify similarities between the river discharge regime, and thus, the factors influencing it. Years of maximal and minimal discharges for major rivers were identified and the impact of large-scale atmospheric circulation processes on the river discharge was studied.

Key words: discharge, long-term variability, trends, wavelet analysis, Baltic region.

\section{INTRODUCTION}

Analysis of patterns of river discharge is important for development of a water resource management system. In light of climate change processes analysis of long-term observations can support the development of prognostic models. Long-term changes of river discharge have been used to study climate variability and climate change impacts (Amarasekera et al., 1997), to study character, return periods and impacts of extreme hydrological processes (floods, droughts) and to validate climate change modelling results. It is well known that hydrological processes have shown periodicity (Williams, 1961). The periodicity of river discharge changes has been previously explained with the Hale cycles (11 and 22 years) and Gleissberg solar activity cycles, solar-lunar tidal periods as well as other periodically occurring processes (Probst and Tardy, 1987; Currie, 1996; Vasiliev and Dergachev, 2002). Recently, periodicity of runoff in European rivers has been shown (Pekarova et al., 2003). A possible explanation of river discharge periodicity might be changes in large-scale atmospheric circulation (Pekarova and Pekar, 2004). However, new methods of examining periodicity of hydrological processes need to be tested.

A multitude of river discharge time series have been determined worldwide (Lins and Slack, 1999; Benit et al., 2003) and in Nordic countries (Vehviläinen and Huttunen, 1997; Lindstrom and Bergstrom, 2004). Analysis of river discharge patterns and flood risk is important for the Baltic region, which is located in a climatic region directly influ- enced by large-scale atmospheric circulation processes over the Northern Atlantic and by continental impacts from Eurasia (Jaagus, 2009).

Studies conducted on river discharge trends in Poland, Estonia and Lithuania confirm the importance of such analysis (Jaagus et al., 1998; Strupczewski et al., 2001; Reihan et al., 2007). Long-term streamflow analysis is needed for effective water resource management and therefore has immense socio-economic significance, particularly considering the predicted changes in this region due to global change.

Wavelet analysis has good time and frequency multiresolution, and can effectively diagnose a signal's main frequency component and abstract local information of a time series. It has huge advances in signal processing and nonlinear science fields. The studies and applications of wavelet analysis have already begun in hydrology and water resources (Brillinger, 1994; Bayazit et al., 2001; Lafreniere and Sharp, 2003; Labat, 2008).

The aim of the present study is to use wavelet analysis to model river discharge and hydrological processes in the rivers of the Eastern coast of the Baltic Sea.

\section{METHODS AND DATA}

The study area covered the eastern part of the Baltic Sea (Fig. 1). The hydrological regime of rivers in this region is influenced not only by the variability of the climate (precip- 


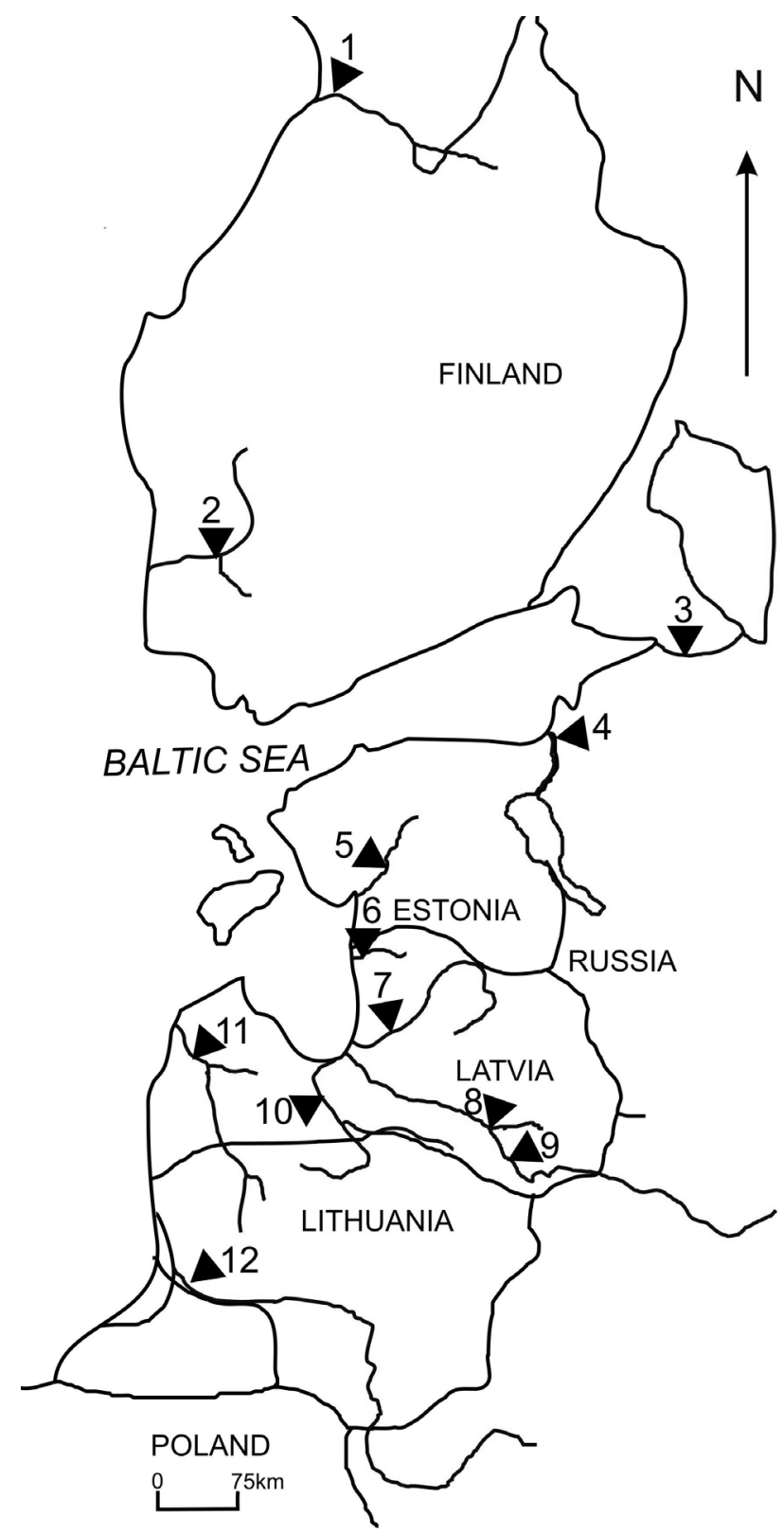

Fig. 1. Location of river gauging stations used for data collection (river discharge (ム) study sites): 1 - Oulujoki (Jylhämä); 2 - Kokemäenjoki (Harjavalta); 3 - Neva (Novosaransk); 4 - Narva (Vasknarva); 5 - Pärnu (Oore); 6 - Salaca (Lagaste); 7 - Gauja (Sigulda); 8 - Dubna (Sili); 9 Daugava (Daugavpils); 10 - Lielupe (Mežotne); 11 - Venta (Kuldīga); 12 - Nemunas (Smalininķai).

itation and air temperature), but also by factors such as geomorphology, geological structure, soil composition, and land-use patterns.

Data used in this study were obtained from the Latvian Environmental, Geological and Hydrometeorological Centre. Before statistical analyses the streamflow data was tested by Fisher test for data homogeneity. The test showed that the variability of time series of river flow was homogenous $\left(\mathrm{F}_{\text {emp }}<\mathrm{F}_{\text {theoretical }}, P=0.05\right)$ for each selected river.

For trend analysis, mean annual discharge values were calculated as arithmetic means from monthly records. For the calculation of the periodic changes (oscillation) of discharge, moving average (step 6 and 10 years) values of dis- charge data as well as integral curves were utilized. The use of integral curves, which depict differences in discharge for each study year in comparison with mean values for all the observation period were used to identify the pattern of discharge. In the calculation, ratio $\mathrm{K}$ was used:

$K=\frac{Q_{i}}{Q_{0}}$ where: $Q_{i}-$ discharge in year i; $Q_{0}-$ mean discharge for the entire period of observation.

Using this approach, the integral curve is produced by summing deviations $\sum(K-1)$. By integration of the deviations, the amplitude of the oscillations increases proportionally to the length of the period, with one-sign deviations in the row. The analyses of integral curves allow precisely identify significant change points of low-water and high-water discharge periods. High-water discharge periods were considered to be years for which $\mathrm{K}>1$, and low-water flow periods were indicated by a $\mathrm{K}<1$.

The multivariate Mann-Kendall test (as described by Hirsch et al., 1982; Hirsch and Slack, 1984) for monotone trends in time series of data grouped by sites was chosen for the determination of trends, as it is a relatively robust method concerning missing data, and it lacks strict requirements regarding data heteroscedasticity. The Mann-Kendall test was applied separately to each variable at each site, at a significance level of $P<0.5$. The trend was considered as statistically significant at the $5 \%$ level if the test statistic was greater than 2 or less than -2 (Hirsch and Slack, 1984).

Spectral analysis of the river discharge changes was conducted using spectral analysis and periodograms (Pekarova et al., 2003). A periodogram is a plot of frequency and ordinate pairs for the studied time period. The graph breaks a time series of discharge into a set of sine waves of various periods $\mathrm{T}$ and shows the frequency spectrum. The spectral density is defined as a mean value of the set of periodogram for $\mathrm{n} \rightarrow \infty$. The periodogram (Pekarova et al. 2003) is calculated according to:

$I(T)=\frac{1}{2 \pi n}\left\|\sum_{k=1}^{n} x_{k} \exp \left(i \frac{2 \pi k}{T n}\right)\right\|$,

where $i=\sqrt{-1}, n$ is observation count (years), $x_{k}$ is observed discharge value.

The wavelet analysis method used was adapted to the needs of the present study. Emphasis is given to useful practical details for applying the method for hydrological time series analysis. The continuous wavelet transformation of a discrete sequence of observations is defined as the convolution of $x(t)$ with a scaled and translated wavelet that depends on a nondimensional time parameter. A Morlet wavelet (Torrence and Compo, 1998; Goswami et al., 1999) is a function defined as $\psi\left(t, T_{0}=\exp \left(t^{2} / 2+i 2 \pi t / T_{0}\right)\right.$. Discharge wavelet decomposition is discharge signal convolution with the Morlet wavelet function

$C\left(t+\Delta t, a \cdot T_{0}\right)=\frac{1}{\sqrt{a}} \int x(t+\Delta t) \psi\left(\frac{t}{a}, T_{0}\right) d t$, 
where $T_{0}$ is a base period, $a=T / T_{0}$ is a scale factor, $\Delta t$ is a shift in time, $x(t)$ is a time series.

Function $I(T)+\int C\left(t, a \cdot T_{0}\right) d t$ describes the energy distribution of pulsation over the scales or frequencies and equivalent to a Fourier spectrum.

Since complex wavelets lead to complex continuous wavelet transformation, the wavelet power spectrum is a convenient description of the fluctuation of the variance at different frequencies. Further, when normalized, it gives a measure of the power relative to white noise. Wavelet analysis allows to observe correlation of a signal on different scales for amplitude and phase.

$$
\begin{aligned}
& R_{i, j}^{a m p l}(\Delta t, T)=\operatorname{cov}\left(\left\|C_{i}(t, T)\right\|,\left\|C_{j}(t+\Delta t, T)\right\|\right)+ \\
& + \text { mean }\left(\left\|C_{i}(t, T)\right\|\right) \cdot \operatorname{mean}\left(\left\|C_{j}(t+\Delta t, T)\right\|\right) \\
& R_{i, j}^{p h}(\Delta t, T)=\operatorname{cov}\left(\operatorname{Arg}\left(C_{i}(t, T)\right), \operatorname{Arg}\left(C_{j}(t+\Delta t, T)\right)\right),
\end{aligned}
$$

where indexes $\mathrm{i}, \mathrm{j}$ denote selected rivers.

For data treatment, the Excel, SPSS, R and Multimk software packages were used.

\section{RESULTS}

The hydrological regime of rivers in flowing into the eastern coast of the Baltic Sea differ in discharge volume, seasonal river discharge variability in spring and autumn, and relative proportion between spring and autumn floods, in relation to many factors (precipitation, evapotranspiration, runoff, temperature).

Trends of changes in river discharge were determined using linear trend analysis, a commonly used approach in the study of river discharge. Table 1 shows the discharge trends in rivers of Latvia and the north-eastern part of the Baltic Sea: the discharge was significantly increased for rivers

Table 1

SIGNIFICANCE OF TEMPORAL CHANGES OF WATER DISCHARGE FOR RIVERS IN THE BALTIC REGION

\begin{tabular}{l|c|c|c|c}
\hline \multicolumn{1}{c|}{ River } & $\begin{array}{c}\text { Period of } \\
\text { observation }\end{array}$ & $\begin{array}{c}\text { Normalised } \\
\text { test statistic }\end{array}$ & $\begin{array}{c}\text { Period of } \\
\text { observation }\end{array}$ & $\begin{array}{c}\text { Normalised } \\
\text { test statistic }\end{array}$ \\
\hline Neva & $1881-2000$ & -0.68 & $1961-2000$ & 1.08 \\
Nemunas & $1896-2006$ & -2.90 & $1961-2006$ & 0.03 \\
Daugava & $1881-2006$ & 0.57 & $1961-2006$ & 2.53 \\
Venta & $1898-2006$ & 1.29 & $1961-2006$ & 0.41 \\
Narva & $1902-2002$ & -0.87 & $1961-2002$ & 2.14 \\
Pärnu & $1922-2002$ & 0.27 & $1961-2002$ & 2.27 \\
Lielupe & $1921-2006$ & -1.08 & $1961-2006$ & 1.64 \\
Salaca & $1927-2006$ & 1.06 & $1961-2006$ & 2.66 \\
Gauja & $1940-2006$ & 1.51 & $1961-2006$ & 2.06 \\
Dubna & $1948-2006$ & 1.38 & $1961-2006$ & 2.41 \\
Oulujoki & $1896-2000$ & -1.36 & $1961-2006$ & 0.05 \\
Kokemaenjoki & $1931-2000$ & 1.89 & $1961-2006$ & 1.49 \\
\end{tabular}

* The trend can be considered as statistically significant at the 5\% level if the test statistic is greater than 2 or less than -2 .
Daugava, Gauja, Narva, Pärnu, Salaca in the period 1961-2000, and the changes are increasing for all of the other studied rivers for the same observation period. For the entire observation period, linear trend analysis shows that a statistically significant decrease of discharge has occurred for River Nemunas, but for all other rivers the trends of changes were statistically not significant.

The changes of river discharge can be analysed not only as linear process, but as periodic processes, since the periodicity of high-water periods and low-water periods is evident (Figs. 2, 3) and discharge of both the largest and medium-sized rivers in the Baltic region do have well expressed periodicity. The periodicity can be expressed using normalised discharge data (Fig. 3) (normalized discharge is calculated as $\tilde{Q}=Q / \operatorname{median}(Q-1)$.

To characterise periodicity and to estimate major periods of river discharge changes, periodograms (Pekarova et al., 2003) were calculated using spectral analysis (Fig. 4). Using this approach, statistically significant periods in annual river discharge in the Baltic region can be identified. The major period of river discharge for all studied rivers had a range from 27-33 years.

The general patterns of periodicity of water flow regime in several major rivers in Latvia are summarized in Table 2. For the last 100-125 years, low-discharge periods for rivers of Latvia are longer than high discharge periods and last from a minimum of ten years up to a maximum of 21-27
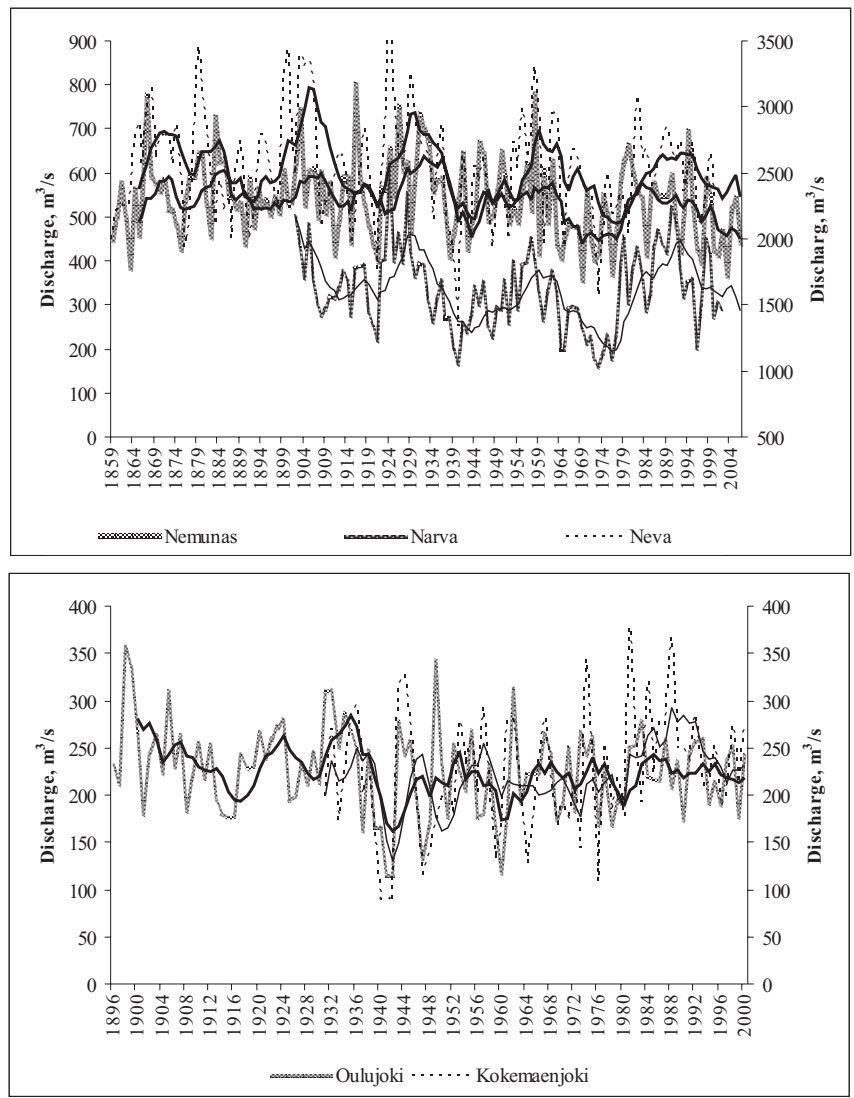

Fig. 2. Long-term change of mean annual discharge of rivers in the Baltic region. Data were normalised and smoothed with a 7-year moving average. 
LOW AND HIGH DISCHARGE PERIODS FOR THE LARGEST RIVERS IN LATVIA

\begin{tabular}{|c|c|c|c|c|c|c|c|}
\hline $\begin{array}{c}\text { Low discharge } \\
\text { period }\end{array}$ & Years & Qmean, $\mathrm{m}^{3} / \mathrm{s}$ & K & $\begin{array}{l}\text { High discharge } \\
\text { period }\end{array}$ & Years & Qmean, $\mathrm{m}^{3} / \mathrm{s}$ & $\mathrm{K}$ \\
\hline \multicolumn{8}{|c|}{ Daugava (1881-2006) } \\
\hline 1881-1901 & 21 & 401 & 0.87 & $1902-1908$ & 7 & 595 & 1.29 \\
\hline 1909-1921 & 13 & 442 & 0.96 & $1922-1936$ & 15 & 549 & 1.19 \\
\hline 1937-1952 & 16 & 419 & 0.90 & $1953-1958$ & 6 & 555 & 1.20 \\
\hline 1959-1985 & 27 & 401 & 0.87 & $1986-2000$ & 19 & 490 & 1.06 \\
\hline 2001-2006 & 6 & 431 & 0.93 & & & & \\
\hline Total, mean & 83 & 419 & 0.91 & & 43 & 552 & 1.19 \\
\hline \multicolumn{8}{|c|}{ Venta (1897-2006) } \\
\hline $1900-1923$ & 24 & 60.2 & 0.92 & $1924-1930$ & 7 & 72.1 & 1.10 \\
\hline 1931-1949 & 19 & 57.0 & 0.87 & 1950-1959 & 10 & 69.9 & 1.07 \\
\hline 1960-1977 & 18 & 57.1 & 0.88 & 1978-2002 & 25 & 79.1 & 1.21 \\
\hline 2003-2006 & 4 & 48.1 & 0.74 & & & & \\
\hline Total, mean & 65 & 55.6 & 0.85 & & 42 & 73.7 & 1.13 \\
\hline \multicolumn{8}{|c|}{ Salaca (1927-2006) } \\
\hline 1933-1952 & 20 & 25.6 & 0.84 & $1927-1932$ & 6 & 44.9 & 1.48 \\
\hline \multirow[t]{2}{*}{ 1963-1976 } & 14 & 22.4 & 0.74 & $1953-1962$ & 10 & 34.6 & 1.14 \\
\hline & & & & $1977-2005$ & 29 & 33.9 & 1.11 \\
\hline Total, mean & 34 & 24.0 & 0.79 & & 45 & 37.9 & 1.25 \\
\hline \multicolumn{8}{|c|}{ Gauja (1940-2006) } \\
\hline 1940-1952 & 13 & 62.5 & 0.89 & $1953-1962$ & 10 & 84.5 & 1.21 \\
\hline 1963-1977 & 15 & 55.8 & 0.80 & $1978-2005$ & 28 & 77.3 & 1.10 \\
\hline Total, mean & 28 & 59.2 & 0.84 & & 38 & 80.9 & 1.15 \\
\hline \multicolumn{8}{|c|}{ Lielupe (1921-2006) } \\
\hline 1933-1942 & 10 & 49.4 & 0.89 & $1921-1932$ & 12 & 71.9 & 1.29 \\
\hline 1963-1977 & 15 & 39.8 & 0.72 & $1943-1962$ & 20 & 61.8 & 1.11 \\
\hline \multirow[t]{2}{*}{ 1984-1997 } & 14 & 48.9 & 0.88 & $1978-1983$ & 6 & 66.3 & 1.19 \\
\hline & & & & $1998-2005$ & 8 & 65.7 & 1.17 \\
\hline Total, mean & 39 & 46.0 & 0.83 & & 46 & 66.4 & 1.19 \\
\hline
\end{tabular}

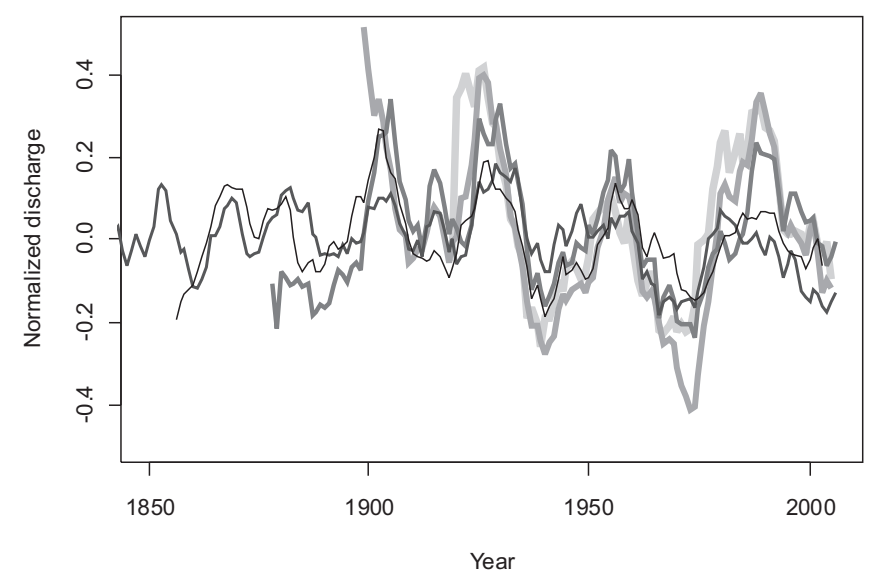

Fig. 3. Long-term changes of discharge of the rivers in the Baltic region calculated as normalised discharge.

years. High-discharge periods extended from 6-8 to 10 years, however, during the last 30 years, for the biggest rivers (except River Lielupe) their duration reached 20 to 27 years. Periodicity of river discharge changes has been noted previously in studies of river discharge in Central Europe (Pekarova et al., 2003).

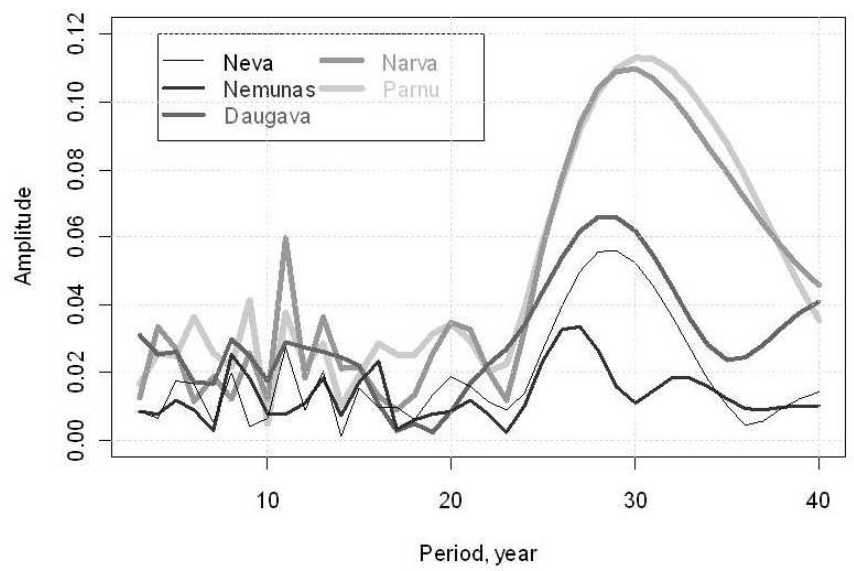

Fig. 4. Periodogram of annual normalised river discharge time series for rivers in the Baltic region.

Wavelet analysis of discharge series is a prospective tool to study river discharge periodicity. Wavelet analysis allows to determine the spectral characteristics of time signals, shown for River Nemunas (Fig. 5) discharge Morlet wavelet decomposition and autocorrelation analysis (white contours and lines indicate sectors in Figure with the highest correlation). 


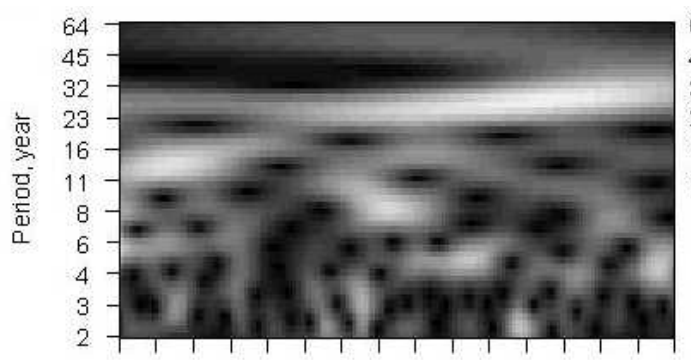

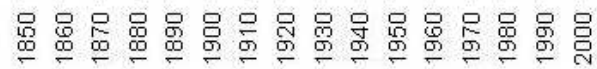

Time, year

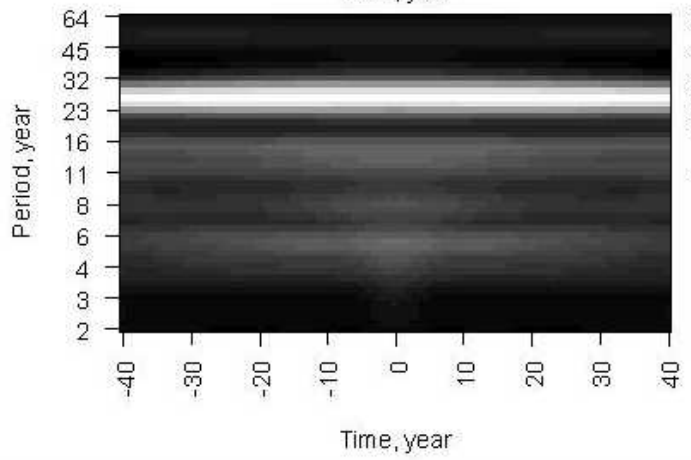

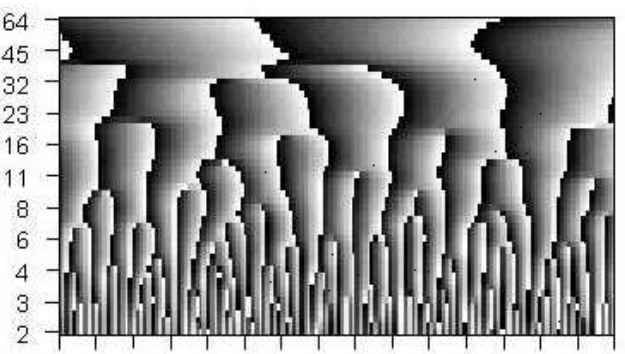

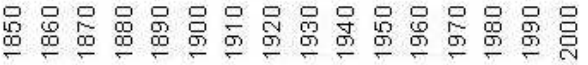

Time, year

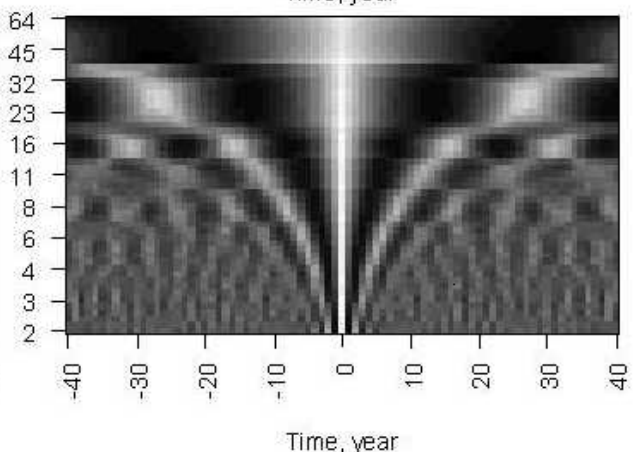

Fig. 5. Morlet wavelet decomposition (amplitude and phase) and autocorrelation (amplitude and phase) of River Nemunas discharge.
Wavelet decomposition amplitude analysis for River Nemunas discharge demonstrates a dominant periodicity spectra with minor periodicities, and wavelet decomposition phase shows that the dominant period of duration $\sim 23-32$ years. The Morlet wavelet autocorrelation amplitude analysis demonstrates the pattern of discharge intensity changes and character, and the autocorrelation phase analysis shows the symmetry of the oscillation phase. Amplitude correlation of river discharge was very low.

Phase analysis of the Baltic region river discharge wavelet decomposition (Fig. 6) shows similarity of discharge periodicity among the major rivers of the Baltic region. In gen- eral, oscillatory patterns of short period differed, but significant similarities occurred in the long period discharge changes.

Wavelet analysis can be used to compare and determine similarities between rivers from differing regions in discharge comparison, as shown by wavelet phase and amplitude correlation calculated for Daugava-Nemunas and Gauja-Nemunas pairs (Fig. 7). While the wavelet phase analysis did not much help in identifying similarities between rivers from different regions, then wavelet amplitude analysis showed that the above pairs of rivers from the Baltic region had similar periodicity of discharge changes.
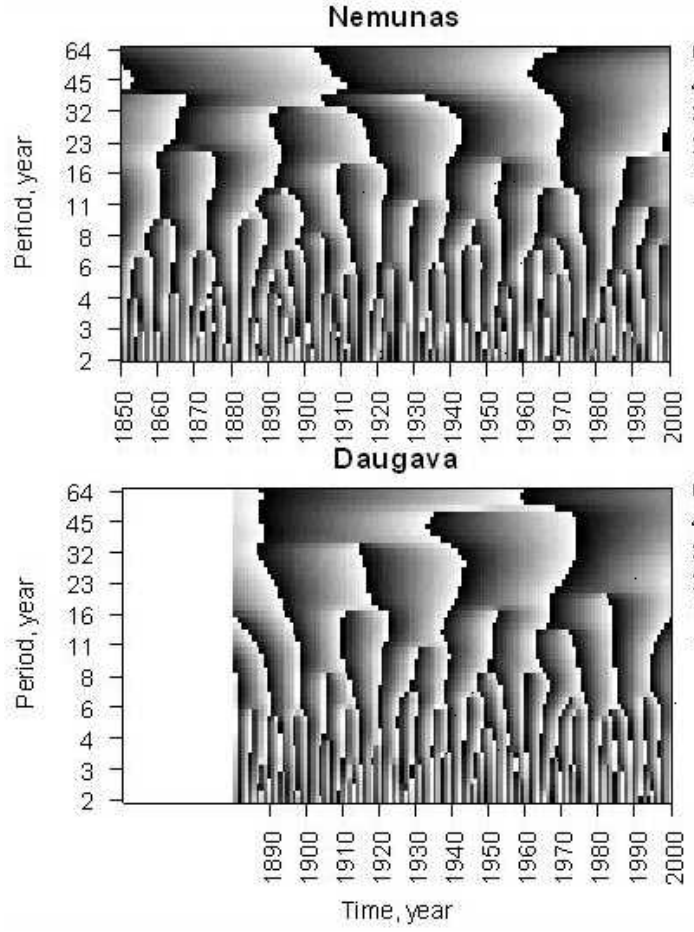
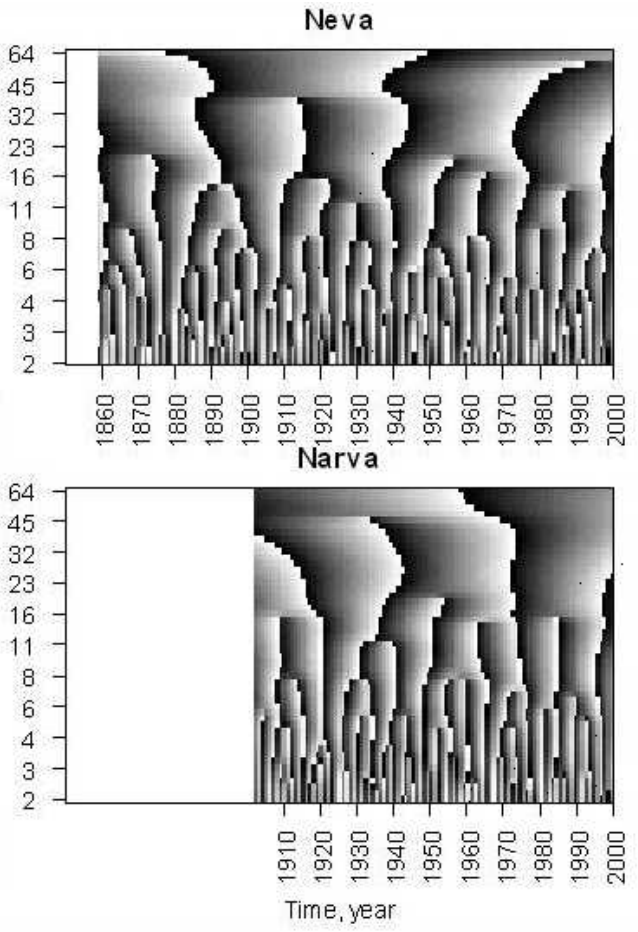

Fig. 6. Phase of Morlet wavelet decomposition of the Baltic region river discharge. 


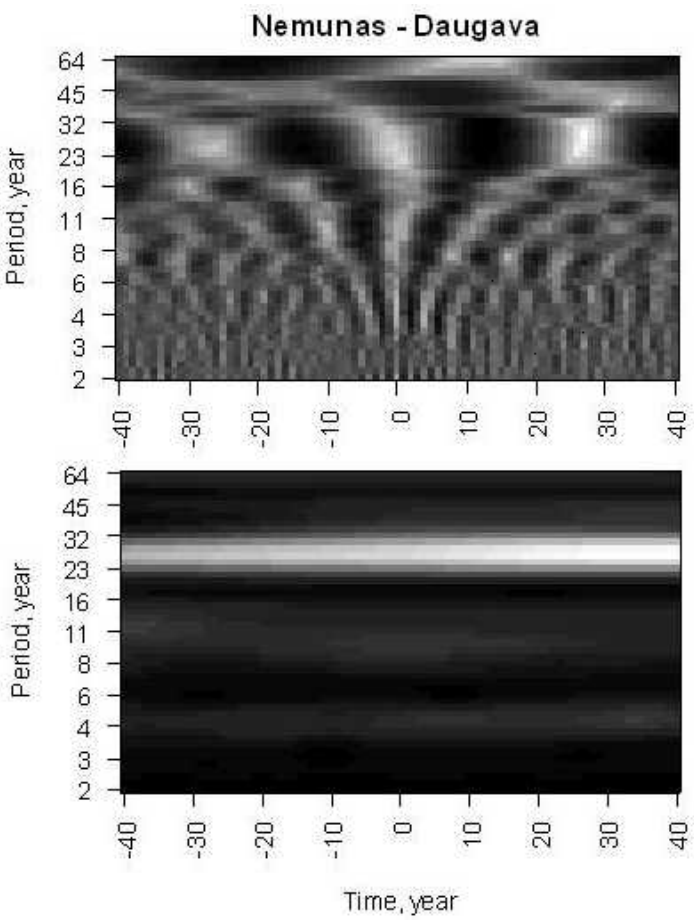

\section{DISCUSSION}

The pattern of changes of the river discharge in the Baltic region is formed by processes affecting discharge in the corresponding hydrological regions, but also to a significant degree the ongoing processes of the climate change. Hydrological processes have mostly been modelled using linear trend analysis methods, but it is known that river discharge in the Baltic region has periodic character. Therefore, the need to utilise methods to analyse river discharge periodicity.

Periodograms (Figs. 2-4) show that the main rivers of the Baltic regions have well pronounced periodicity of discharge and high and low water periods (Table 2). Periodograms or Fourier representation of a river discharge allow to understand the mean energy of the frequency and wavelet decomposition shows how energy of the frequency is accumulated over time.

Wavelet analysis can be considered as an efficient tool for studies of climatological and meteorological data series, in contrast to the Fourier analysis, as it can help to determine spectral changes in time. The module of the wavelet coefficient (complex number) characterises the amplitude of oscillation for the selected time and time period (scale), and the argument of the wavelet coefficient characterises the phase of the oscillation. Thus, the continuous horizontal white strip in the wavelet amplitude graph (Figs. 5, 7) indicates that an oscillation is constantly present in the time series, corresponding to the period characterizing the strip. In the case of rivers of the Baltic region this period is 23-32 years. The less expressed correlated oscillation periods are 8, 11 and 16 years. Accurate contours in the phase wavelet graph correspond to a change of the phase of oscillation by one period (Figs. 5, 6). In the phase diagram, the distance between the color isolines indicates the periodicity of the

\section{Nemunas - Gauja}

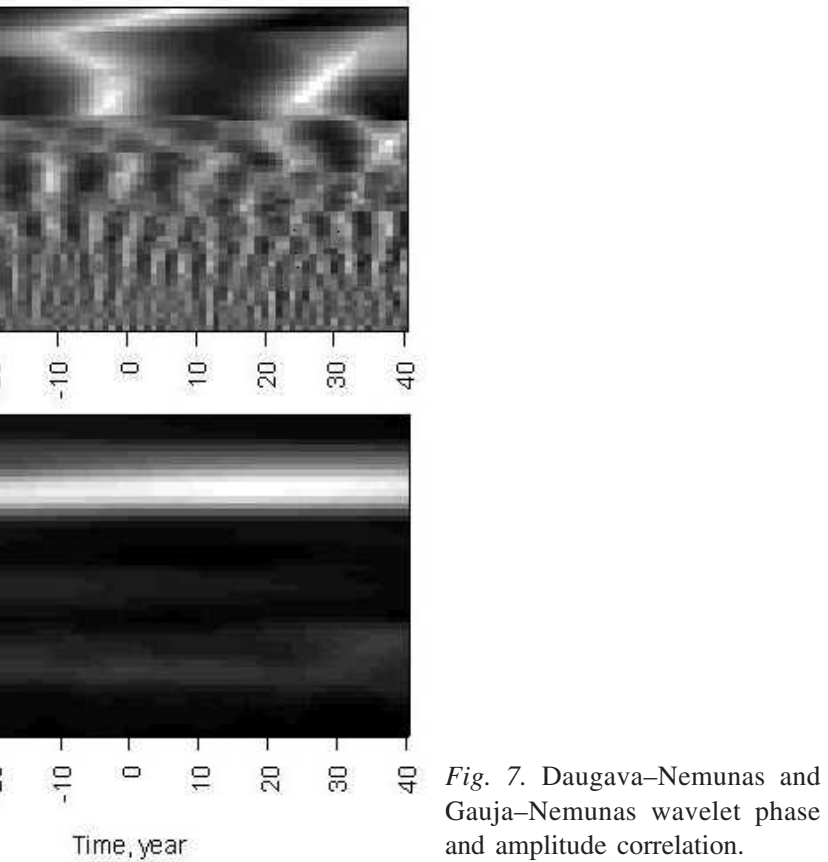

oscillation. In cases of equidistant displacement of color isolines along the horizontal line, the distance corresponds to the permanent oscillation period (Fig. 5). Correlations of wavelet coefficient amplitude show similarity of oscillation amplitudes in the selected period (scale) for a given displacement in time, and also amplitude importance (energy). Correlations of the phases show similarity of phases for the given displacement and scale. Thus, the horizontal distance between light spots specifies the period of fluctuations, and a shift from the central vertical line indicates difference of phases between signals for the selected period. The wavelet correlations graph suggests basic periods of river discharge fluctuations to be 30,11 and 4 years, but the amplitude of fluctuations for any period strongly varies in time (Fig. 6).

The conclusions are that the river discharge regime in the Baltic countries during last centuries has undergone major changes and has well-expressed periodicity: basic periods of river discharge fluctuations are 30, 11 and 4 years. Wellexpressed regular changes of high water and low water periods are evident. Both Fourier analysis (periodograms) and wavelet analysis confirms the periodicity of the river discharge changes and this aspect should be considered in development of hydrological and climate change models. The efficiency of wavelet analysis shows that this method can be applied in studies of climatological and meteorological parameters.

\section{REFERENCES}

Amarasekera, K.N., Lee, R.L., Williams, E.R., Eltahir, E.E.B. (1997). ENSO and the natural variability in the flow of tropical rivers. J. Hydrol., 200, 24-39.

Bayazit, M., Onoz, B., Aksoy, H. (2001). Nonparametric streamflow simulation by wavelet or Fourier analysis. Hydrol. Sci., 46(4), 623-634. 
Benit, G., Diez-Herrero, A., de Villalta, M.F. (2003). Magnitude and frequency of flooding in the Tagus basin (Central Soain) over the last millennium. Clim. Change, 58, 171-192.

Brillinger, D. (1994). Some river wavelets. Environmetrics, 211-220.

Currie, R.G. (1996). Variance contribution of luni-solar (Mn) and solar cycle (Sc) signals to climate data. Int. J. Climatol., 16, 1343-1364.

Goswami, J. C., Chan, A.K. (1999). Fundamentals of Wavelets Theory, Algorithms, and Applications. New York: Wiley. 319 pp.

Hirsch R.M., Slack J.R. (1984). A nonparametric trend test for seasonal data with serial dependence. Water Resources Res., 20(6), 727-732.

Hirsch, R.M., Slack, J.R., Smith, R.A. (1982). Techniques of trend analysis for monthly water quality data, Water Resources Res., 18(1), 107-121.

Jaagus, J., Järvet, A., Roosaare, J. (1998). Modelling the climate change impact on river runoff in Estonia. In: Climate Change Studies in Estonia (pp. 117-127). T. Kallaste, P. Kuldna (eds.). Tallinn: Stockholm Environment Institute Tallinn Centre.

Jaagus, J. (2009). Regionalisation of the precipitation pattern in the Baltic Sea drainage basin and its dependence on large-scale atmospheric circulation. Boreal Environ. Res., 13, 31-44.

Labat, D. (2008). Wavelet analysis of the annual discharge records of the world's largest rivers. Adv. Water Resources, 31(1), 109-117.

Lafreniere, M., Sharp, M. (2003). Wavelet analysis of inter-annual variability in the runoff regimes of glacial and nival stream catchments, Bow Lake, Alberta. Hydrol. Process, 17, 1093-1118.
Lins, F.H., Slack, J.R. (1999). Streamflow trends in the United States, Geophys. Res. Lett., 26(2), 227-230.

Lindstrom, G., Bergstrom, S. (2004). Runoff trends in Sweden 1807-2002. Hydrol. Sci. J., 49(1), 69-83.

Probst, J., Tardy, Y. (1987). Long range streamflow and world continental runoff fluctuation since beginning of this century. J. Hydrol., 94, 289-311.

Pekarova, P., Miklanek, P., Pekar, J. (2003). Spatial and temporal runoff oscillation analysis of the main rivers of the world during the 19th-20th centuries. J. Hydrol., 274, 62-79.

Pekarova, P., Pekar, J. (2004). Teleconnections AO, NAO, SO and QBO with interannual streamflow fluctuations in the Hron basin. J. Hydrol. Hydromechan., 52, 279-294.

Reihan, A., Koltsova, T., Kriauciuniene, J., Lizuma, L. MeilutyteBarauskiene, D. (2007). Changes in water discharges of the Baltic states rivers in the 20th century and its relation to climate change. Nordic Hydrol., 38(4/5), 401-412.

Torrence, C., Compo, G.P. (1998). A practical guide to wavelet analysis. Bull. Amer. Meteorol. Soc., 79, 61-78.

Vasiliev, S.S., Dergachev, V.A. (2002). The approximate to 2400 -year cycle in atmospheric radiocarbon concentration: Bispectrum of C-14 data over the last 8000 years. Ann. Geophys., 20, 115-120.

Vehviläinen, B. Huttunen, M. (1997). Climate change and water resources in Finland, Boreal Env. Res., 2(1), 3-18.

Williams, G.R. (1961). Cyclical variations in the world-wide hydrological data. J. Hydraul. Div. ASCE, 6, 71-88.

Received 22 January 2010

\section{BALTIJAS REG̦IONA UPJU NOTECES MAINĪBAS RAKSTURA IZPĒTE, IZMANTOJOT VEIVLETANALĪZI}

Pētīta Baltijas reǵiona upju (no Somijas līdz Lietuvai) noteces ilgtermiṇa mainības raksturs. Izmantojot gan Furjēe spektrālo, gan veivletanalīzi, pierādīts, ka Baltijas reǵiona upju noteces režīmu raksturo izteikts periodiskums un tā mainībai ilgstošā laika periodā ir oscilējošs raksturs. Dominējošā mainības frekvence ir 22-30 gadi, bet tipiski ir arī îsāka perioda mainības cikli. Veivletanalīze uzskatāma par efektīvu instrumentu upju noteces mainības izpētei. 